\title{
Endelomyia filipendulae Lacourt, 1998 new record for the Hungarian fauna (Hymenoptera: Symphyta)
}

\author{
AtTILA Haris
}

H-1076 Budapest, Garay u. 19. 2/20; email: attilaharis@yahoo.com

HARIS, A.: Endelomyia filipendulae Lacourt, 1998 new record for the Hungarian fauna (Hymenoptera: Symphyta).

Abstract: Endelomyia filipendulae Lacourt, 1998 is recorded first time from Hungary, one female from Gánt, Fejér county and one female from Somogyszob, Somogy county.

Keywords: Hymenoptera, Symphyta, Tenthrdinidae, new record for Hungary

\section{Introduction}

Endelomyia Ashmead, 1898 is a small genus of subfamily Heterarthrinae with 3 species. Two of them are described subrecently, namely Endelomyia filipendulae Lacourt, 1998 and Endelomyia marginata (Wei, 1998). The second European species has been overlooked till 2020 when Ladislav Roller (in SMETANA et al. 2020) revised the old material and reported it from NPR Devínska Kobyla: Sandberg.

\section{Material and methods}

Receiving the paper of SMETANA et al. 2020 and the monograph of MACEK et al. 2020, the author started the reidentification of the sawfly material of Rippl-Rónai Museum in Kaposvár. For safe indentification, the study of female genitalia was necessary. For identification, the mongraphs of MACEK et al. 2020 and LACOURT 2020 were used. Two females of Endelomyia filipendulae Lacourt, 1998 were identified. These 2 females were overlooked as Endelomyia aethiops (Gmelin, 1790) and published in HARIs 2010, 2012.

\section{Results}

Endelomyia filipendulae Lacourt, 19981 female, on 15. 04. 2010. at Gánt: around $47^{\circ} 27^{\prime} 40.89^{\prime \prime} \mathrm{N}, 18^{\circ} 27^{\prime} 17.10^{\prime \prime}$ E., dry dolomite grassland and bushy area along the tourist road, and 1 female, on 17. 04. 2012 at Somogyszob: Kaszó: Kanizsaberek Southern part, between $46^{\circ} 19^{\prime} 41.41^{\prime \prime} \mathrm{N}, 17^{\circ} 12^{\prime} 3.69^{\prime \prime} \mathrm{E}$ and 46 $16^{\prime} 24.72^{\prime \prime} \mathrm{N}, 17^{\circ} 11^{\prime} 47.51^{\prime \prime} \mathrm{E}, 27.04$. 2012. Both specimen were collected by the author. 


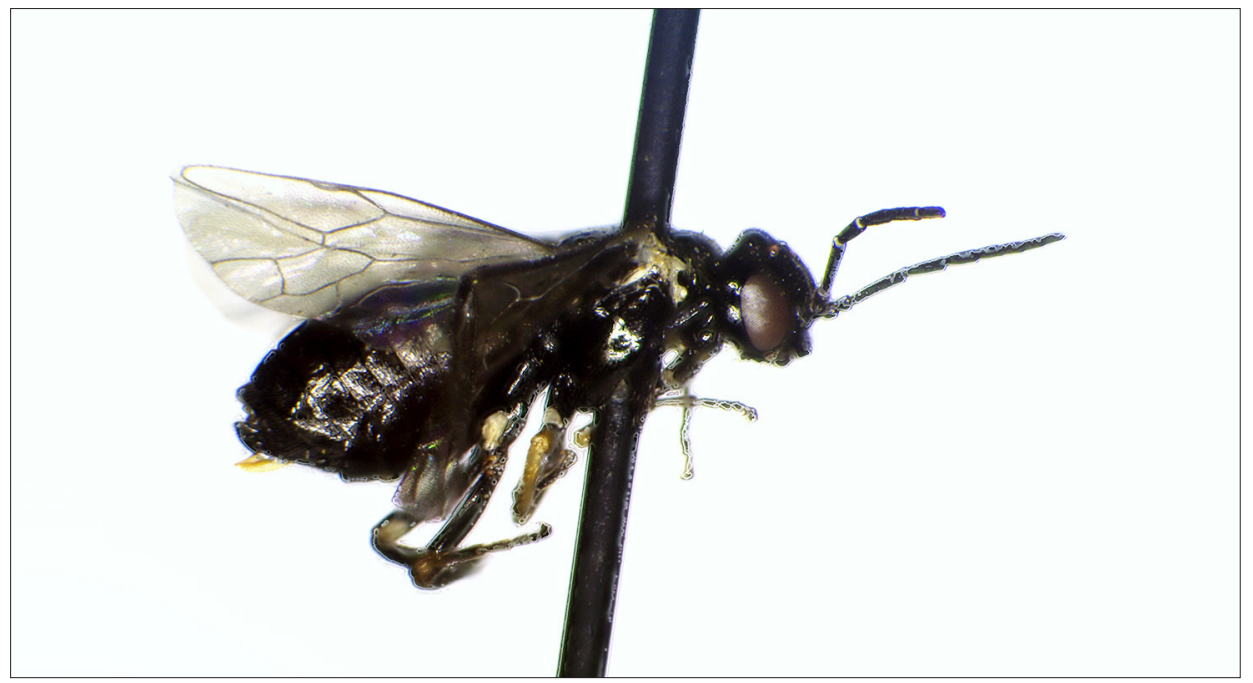

Fig. 1: Endelomyia filipendulae Lacourt, 1998 female

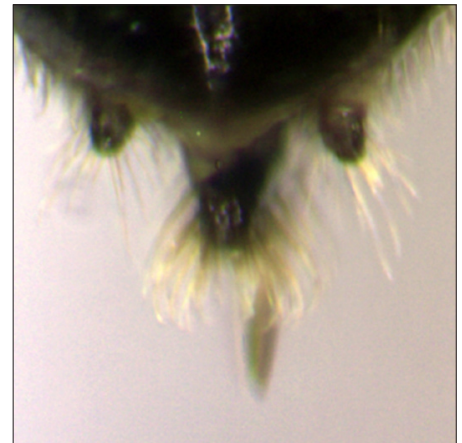

Fig. 2: Sawsheath of Endelomyia filipendulae Lacourt, 1998

Description: Body black, white: cenchri, apical third of anterior and middle femora, whole antrior and middle tibiae, ventral side of antrior and middle basitarsi (Fig. 1). Clypeus subtruncate, occipital carina missing. Head parallel behind eyes. Head smooth and shiny. Gena narrow, about $0.4 \mathrm{x}$ as wide as diameter of anterior ocellus. Frontal basin sunken with well defined border without carina. Postolcellar furrows deep and divergent. Head and thorax with short, sparse and dark pubescence. Anterior and lateral lobe of mesonotum, mesoscutellum with deep, moderaely large, moderately dense punctures, shiny. Mesopleuron and mesosternum smooth and shiny. Mesoscutellar appendage with superficial transverse sculpture, shiny. Metascutellum with dense transverse sculpture, matt. All abdominal tergites with coriaceous surface sculpture, shiny. Claw with developed basal lobes without subapical tooth. Inner hind tibial spur about as long as tibial apical width.

Differences from E. aethiops: E. filipendulae has sawsheath with long setae that are clearly incurved at the apex (Fig. 2) while in E. aethiops, sawsheath with short, almost straight setae. 
From the Carpathian Basin out of Hungary, we have record from Slovakia: NPR Devínska Kobyla - Sandberg, 23. 04. 2015, 2 females, L. Roller lgt. et coll. (SEMTANA et al. 2020). From Europe, it is also known from France and Germany (LACOURT 1998, 1999, Liston et al. 2006). Larvae on Filipendula vulgaris.

\section{References}

HaRIs, A. 2010: Sawflies of the Vértes Mountains (Hymenoptera: Symphyta). - Natura Somogyiensis 17: 221250.

HaRIS, A. 2012: Sawflies of Belső-Somogy (Hymenoptera: Symphyta). - Natura Somogyiensis 22: 141-162.

LACOURT, J. 1998: Endelomyia filipendulae, nouvelle espèce du sud de la France (Hymenoptera, Tenthredinidae). - Bulletin de la Société Entomologique de France, Paris 103(4): 393-394.

LACOURT, J. 1999: Répertoire des Tenthredinidae ouest-paléarctiques (Hymenoptera, Symphyta). - Mémoires de la SEF, Paris 3: 1-432.

LaCourT, J. 2020: Sawflies of Europe: Hymenoptera of Europe 2 N. A. P. Editions. - Verriéres-le-Buisson 876 pp.

Liston, A. D., TAEger, A. \& Blank, S. M. 2006: Comments on European Sawflies (Hymenoptera: Symphyta). - pp. 245-263. In: Blank, S. M., Schmidt, S., \& Taeger, A. (eds.) 2006: Recent Sawfly Research: Synthesis and Prospects. - Goecke \& Evers, Keltern: 704 pp.

MaceK, J., Roller, L., Beneš, K. Holý, K. \& HolušA, J. 2020: Blanokř́́dlí České a Slovenské republiky II. Širopasí. - Academia Praha. 669 pp.

Smetana,V., Roller, L., Benda, D., Bogusch, P., Holý, K., Karas, Z., Purkart, A., Ř́íha, M., Straka, J., Šima, P., Erhart, J., Halada, M., Holecová, M., Horák, J., Klesniaková, M., Macek, J., Pavlíková, A., Petrákoví, L. \& Rindoš, M. 2020: Blanokridlovce (Hymenoptera) ny vybranych lokalitách Malych Karpát. - Acta Musei Tekovensis Levice Zbornik Tekovského Múzea v Leviciach 12: 75-141. 
